\title{
Bioactivity of 7-Hydroxy 4-Methyl Coumarin
}

\author{
Gami Bansuri*, Jalak Limbasiya and Maitri Nandasana \\ Department of microbiology, R.K. University, Kasturbadham (Tramba), \\ Rajkot, Gujarat, India \\ *Corresponding author
}

\section{Keywords}

Coumarin, Toxic effects, Bioactivity, Pseudomonas spp.

Article Info

Accepted:

20 March 2019

Available Online:

10 April 2019

\section{A B S T R A C T}

Coumarin and its derivatives are heterocyclic compounds which gives toxic effects when it is used in higher quantity. In lower amount it is also toxic to marine plants and animals like fish, phytoplanktons, zooplanktons etc. According to various data it is confirmed that coumarin can be harmful for human being also though it is used in cosmetics, pharmaceutical industries and various medicines like anti-cancer and anti-coagulant. Present investigation is focused towards isolation of Pseudomonas fluorescens from different places near Rajkot area in Gujarat state and checks their activity against 7hydroxy-4-methylcoumarin. Total 10 isolates were isolated from these soil samples from that isolates 3 were identified as Pseudomonas fluorescens per their biochemical and morphological properties and their fluorescens under UV exposure. Different biochemical and antibiotic susceptibility test were performed for all these 10 isolates. To check the activity against 7-hydroxy-4- methylcoumarin Compound was dissolved in n- propanol and was given to all 10 isolates by making well in sterile petriplates containing King's B Base medium. Some of these organisms were resistant to the coumarin.

\section{Introduction}

Pseudomonas fluorescence bacteria, a major constituent of rhizobacteria, encourage the plant growth through their different mechanisms (Noori et al., 2012). Pseudomonas fluorescens included a group of common, nonpathogenic saprophytes that colonize soil, water and plant surface environments.

It is a common gram negative, rod-shaped bacterium. As its name involve, it secretes a soluble greenish fluorescent pigment called fluorescein, particularly under conditions of low iron availability. It is an obligate aerobe, except for some strains that can utilize $\mathrm{NO}_{3}$ as an electron acceptor in place of $\mathrm{O}_{2}$. It is motile by means of multiple polar flagella. Pseudomonas fluorescence has simple nutritional requirements and grows well in mineral salts media enriched with any of many carbon sources (Palleroni et al., 1984). Bioremediation term referred as use of biologically mediated agent/process to detoxify, degrade or transform pollutants to harm-less state (Gami et al., 2018). 


\section{Toxic or harmful content and microbes}

Coumarin is an important group of naturally occurring compounds widely distributed in the living kingdom. However, they have been produced synthetically for many years for commercial use. Coumarin and its derivatives have been studied for physiological activity. The coumarin derivatives find their applications in pharmaceutical, fragrance, agrochemical industries, optical brightening agent, dispersed fluorescent and anticoagulant (Gunnewegh et al., 1995). Many derivatives of coumarin is subject to restrictions on its use in perfumery, as some people may become sensitized to it, however the evidence that coumarin can cause an allergic reaction in humans is disputed.

\section{Materials and Methods}

The present study was carried out at the Department of Microbiology, School of Science, R.K. University, Rajkot, Gujarat on "Isolation, biochemical characterization and application of Pseudomonas fluorescens FOR the degradation of 7-hydroxy- 4 methylcoumarin".

Soil sample were collected from university campus and Vavdi industrial area, Rajkot district, Gujarat. The material used and methods employed in the investigation are outlined below. The general laboratory techniques followed in the present study for preparation of media, sterilization, isolation and maintenance of bacterial culture, with slight modification whenever necessary.

\section{Soil sample collection}

Three different samples were collected from different contaminated soil (samples were collected from $10 \mathrm{~cm}$ depth of soil).(I) Industrial metal polluted soil(II) Sewage treated rhizospheric soil(III) Metal polluted sewage treated rhizospheric soil.

\section{Isolation of Pseudomonas fluorescence}

For isolation of Pseudomonas fluorescence 1 gm. of soil was taken from each soil sample in a test tube containing $10 \mathrm{ml}$ of sterile distilled water. After normal vortex the tubes were set and allowed to settle down the soil particles. The serial dilutions were prepared up to $10^{-9}$ dilutions.

For Pseudomonas spp. $-10^{-7}$ to $10^{-9}$ dilutions were taken and $0.1 \mathrm{ml}$ of respective dilutions were spreaded on sterilized petriplates containing Nutrient agar medium and the petriplates were incubated at room temperature $\left(28^{0} \mathrm{C} \pm 2^{0} \mathrm{C}\right)$ for $24-72$ hours.

After incubation the selected colonies were transferred on the sterilized petriplates containing specific media i.e., King's B Base Medium. The plates were incubated at room temperature $\left(28^{0} \mathrm{C} \pm 2^{0} \mathrm{C}\right)$ for 24 hours.

Two replicates were maintained for each dilution. The plates were examined daily up to 3 days for bacterial colonies. Pure cultures of isolated colonies were obtained by the streak plate method.

\section{Identification of bacterial isolates}

All the 10 isolates were checked for their purity and then studied for the colony morphology and pigmentation. The cell shape, Gram reaction, Motility test, and biochemical characterization were also recorded as per the standard procedures.

\section{Results and Discussion}

\section{Isolation of Pseudomonas fluorescens}

From different metal contaminated soil, we had isolated 10 different organisms from which 5 organisms were of Pseudomonas spp. and from that 5 organisms 3 were Pseudomonas fluorescens. From gram 
staining and their morphological characteristics, it was concluded that the organisms are of Pseudomonas spp. The table
1 shows the Gram nature of each isolates and their morphological characteristics (Table 14).

Table.1 Colony morphology and Gram characteristics

\begin{tabular}{|c|c|c|c|c|c|c|c|c|c|c|}
\hline Org. & IMCS-1 & IMCS-2 & IMCS-3 & IMCS-5 & IMCS-7 & IMCS-8 & IMCS-9 & CSTS-11 & MPRS20 & MPRS21 \\
\hline Size & Medium & Medium & Medium & Medium & Medium & Large & Medium & Medium & Medium & Medium \\
\hline Shape & Round & Round & Round & Round & Round & Irregular & Round & Round & Round & Round \\
\hline Color & White & White & White & White & White & White & White & White & White & White \\
\hline Elevatin & Convex & Convex & Convex & Raised & Convex & Flat & Raised & Convex & Convex & Convex \\
\hline $\begin{array}{c}\text { Opacity } \\
\text { Consistency }\end{array}$ & Opaque & Opaque & Opaque & Translucnt & Opaque & Opaque & Opaque & Opaque & Opaque & Opaque \\
\hline $\begin{array}{c}\text { Margin } \\
\text { Gram } \\
\text { Character }\end{array}$ & Entire & Eutyrous & Butyrous & Moist & Butyrous & Dry & Dry & Butyrous & Butyrous & Butyrous \\
\hline \begin{tabular}{c} 
Motility \\
\hline
\end{tabular} & Motile & Entire & Entire & Entire & Undulate & Entire & Entire & Entire & Entire \\
\hline
\end{tabular}

Table.2 Biochemical test results

\begin{tabular}{|c|c|c|c|c|c|c|c|c|c|c|}
\hline $\begin{array}{l}\text { Biochemical } \\
\text { test }\end{array}$ & IMCS-1 & IMCS-2 & IMCS-3 & IMCS-5 & IMCS-7 & IMCS-8 & IMCS-9 & CSTS-11 & MPRS-20 & MPRS-21 \\
\hline Methyl red & + & - & - & + & + & - & + & + & + & + \\
\hline $\begin{array}{l}\text { Voges- } \\
\text { proskauer }\end{array}$ & - & - & - & - & - & - & - & - & - & - \\
\hline $\begin{array}{l}\text { Citrate } \\
\text { utilization }\end{array}$ & + & + & + & + & + & + & + & + & - & - \\
\hline $\begin{array}{l}\text { Indole } \\
\text { production }\end{array}$ & - & - & + & + & - & - & - & - & - & - \\
\hline $\begin{array}{l}\text { Ammonia } \\
\text { production }\end{array}$ & + & + & - & + & + & - & + & - & + & - \\
\hline $\begin{array}{l}\text { Urea } \\
\text { hydrolysis }\end{array}$ & + & + & + & + & + & + & + & + & + & + \\
\hline $\begin{array}{l}\text { Phenylalanine } \\
\text { deamination }\end{array}$ & - & - & - & - & - & - & - & - & - & - \\
\hline $\begin{array}{l}\text { Nitrate } \\
\text { reduction }\end{array}$ & - & - & - & - & - & - & - & - & - & - \\
\hline $\begin{array}{l}\text { Starch } \\
\text { hydrolysis }\end{array}$ & + & + & + & + & - & - & + & - & + & + \\
\hline $\begin{array}{l}\text { Lipid } \\
\text { hydrolysis }\end{array}$ & - & - & - & - & - & - & - & - & - & - \\
\hline $\begin{array}{l}\text { Triple sugar } \\
\text { iron }\end{array}$ & - & + & - & - & + & + & - & - & + & - \\
\hline Hemolysis & - & + & - & - & + & - & + & + & + & + \\
\hline
\end{tabular}


Table.3 Antibiotic susceptibility result

\begin{tabular}{|l|l|l|l|l|l|l|l|l|l|l|}
\hline Name of Antibiotic & IMCS & $\begin{array}{l}\text { IMCS } \\
\mathbf{- 1}\end{array}$ & $\begin{array}{l}\text { IMCS } \\
\mathbf{- 2}\end{array}$ & $\begin{array}{l}\text { IMCS- } \\
\mathbf{- 3}\end{array}$ & $\begin{array}{l}\text { IMCS } \\
\mathbf{- 7}\end{array}$ & $\begin{array}{l}\text { IMCS- } \\
\mathbf{8}\end{array}$ & $\begin{array}{l}\text { IMCS } \\
\mathbf{- 9}\end{array}$ & $\begin{array}{l}\text { CSTS } \\
\mathbf{- 1 1}\end{array}$ & $\begin{array}{l}\text { MPRS } \\
\mathbf{- 2 0}\end{array}$ & $\begin{array}{l}\text { MPRS } \\
\mathbf{- 2 1}\end{array}$ \\
\hline Vancomycin(VA-30) & - & 1.5 & - & 0.9 & 1 & 1 & 1.2 & 1 & 1.4 & 0.9 \\
\hline Streptomycin(S-10) & 1 & 1 & - & 0.5 & 0.7 & 1.6 & 1.3 & - & - & 1 \\
\hline Tetracyclin(TE-30) & 0.5 & 1.2 & 0.7 & 1.4 & 1.2 & 1.4 & 1.7 & 0.7 & 1 & 1.4 \\
\hline Ciprofloxacin(CIP-5) & 1.4 & 1.5 & 1.1 & 2.3 & 1.3 & 1.5 & 2.1 & 1.5 & 1.3 & 0.8 \\
\hline Erythromycin(E-15) & - & 0.6 & 0.7 & 0.9 & 1.2 & 1.4 & 2 & - & 1 & 0.5 \\
\hline Amphicillin(AMP-10) & - & 2.5 & 0.9 & 3 & 1.9 & 1.3 & 1 & 0.9 & 1.4 & 1.3 \\
\hline Cloramphenicol(C-30) & 1.1 & 1 & 1.3 & 2 & 1.3 & 1 & 0.7 & 0.8 & 1 & 0.9 \\
\hline Polymexin(PB-300) & 0.6 & 0.7 & 0.5 & 0.8 & 0.6 & 0.6 & 0.6 & 0.6 & 1.2 & 0.9 \\
\hline Kanamycin(K-30) & 0.9 & 1 & 0.8 & 1.5 & 1 & 0.9 & 1.5 & 0.8 & 1.7 & 2 \\
\hline Penicillin-G(P-10) & - & 2.2 & 0.7 & 2.4 & 1.3 & 1.6 & 0.7 & 0.7 & 1.5 & 0.9 \\
\hline Zentamycin(GEN-10) & 1 & 1.1 & 1 & 1.4 & 1 & 1.2 & 1.5 & 1 & 1.7 & 1.3 \\
\hline Rifampicin(RIF-5) & 0.3 & 1.2 & 0.5 & 1.6 & 1.5 & 1 & 2 & 1 & 2.5 & 0.7 \\
\hline Methicillin(MET-5) & - & 1.2 & - & 1.9 & 1.3 & - & 0.5 & - & - & - \\
\hline
\end{tabular}

Table.4 Zone size after 7-hydroxy-4-methylcoumarin exposure

\begin{tabular}{|l|l|l|}
\hline ORGANISM & CONTROL & $\mathbf{3 0} \boldsymbol{\mu L}$ \\
\hline IMCS: 1 & $0.5 \mathrm{~mm}$ & $3.0 \mathrm{~mm}$ \\
\hline IMCS:2 & $0.5 \mathrm{~mm}$ & $4.0 \mathrm{~mm}$ \\
\hline IMCS:3 & $0.5 \mathrm{~mm}$ & $5.0 \mathrm{~mm}$ \\
\hline IMCS:5 & - & $5.0 \mathrm{~mm}$ \\
\hline IMCS:7 & - & $3.0 \mathrm{~mm}$ \\
\hline IMCS:8 & - & $5.0 \mathrm{~mm}$ \\
\hline IMCS:9 & - & $5.0 \mathrm{~mm}$ \\
\hline CSTS:11 & - & $2.0 \mathrm{~mm}$ \\
\hline MPRS:20 & - & - \\
\hline MPRS:21 & $1.0 \mathrm{~mm}$ & - \\
\hline
\end{tabular}

Activity against 7-hydroxy-4-methylcoumarin

To check the activity against 7-hydroxy-4methylcoumarin, 1000ppm concentration of the compound in three different volumes were given to all the isolates. From all 10 isolates only two isolates showed resistance towards 7-hydroxy-4-methylcoumarin and that were MPRS-20 and MPRS-21. The zone size obtained after the exposure and incubation period is given as per shown in table 4 .

In conclusion, isolation study of the plant growth promoting rhizobacteriaPseudomonas fluorescens is completed by following serial dilution and platting technique by means of different morphological characteristics; staining technique and hanging drop technique.

For specific characterization different biochemical tests were performed. In which IMCS-1, IMCS-2, IMCS-3, MPRS-20 and MPRS-21 gave all tests positive which indicates that the isolates are of Pseudomonas spp.

The compound which we have taken, coumarin has two forms: some of its derivatives are toxic and some of them are 
non-toxic. In case of 7-hydroxy-4methylcoumarin, it cause skin irritation and may harmful to living system. By performing antimicrobial activity many organisms were found resistance towards compound; to overcome coumarin toxicity.

\section{References}

Farinola, N., Piller, N. Pharmacogenomics: Its role in re-establishing coumarin as treatment for lymphedema. Lymphatic Research and Biology. 3 (2): 8186.2005.

Guillemette, A. Recherchessur la matièrecristalline du mélilot. Research into the crystalline material of melilot. Journal de Pharmacie. 21(5): 172-178, 1835.

Karl Paul Link. The discovery of dicumarol and its sequels. Circulation. 19 (1): 97107,1959 .

Leal, L. K. A. M., Ferreira, A. A. G., Bezerra, G. A., Matos, F. J. A., Viana, G. S. B. Antinociceptive, anti-inflammatory and bronchodilator activities of Brazilian medicinal plants containing coumarin: a comparative study. Journal of Ethnopharmacology. 70(2): 151-159, 2000.

Lino C. S., Taveira, M. L., Viana, G. S. B., Matos, F. J. A. Analgesic and antiinflammatory activities of Justicia pectoralis Jacq. and its main constituents: coumarin and umbelliferone. Phytotherapy Research. 11 (3): 211-215,1997.

Perkin W. H. On the artificial production of coumarin and formation of its homologues. Journal of the Chemical Society, 21(11): 53-63, 1868.

Tsutomu Hatano Phenolic Constituents of Licorice. IV. Correlation of Phenolic Constituents and Licorice Specimens from Various Sources, and Inhibitory Effects of Licorice Extracts on Xanthine Oxidase and Monoamine. Yakugakuzasshi. Journal of the Pharmaceutical Society of Japan, 111(6): 311-321,1991.

Wessling, J. Neurological outcome in schoolage children after in utero exposure to coumarins. Early Human Development, 63(2), 83-95, 2001.

\section{How to cite this article:}

Gami Bansuri, Jalak Limbasiya and Maitri Nandasana. 2019. Bioactivity of 7-Hydroxy 4Methyl Coumarin. Int.J.Curr.Microbiol.App.Sci. 8(04): 2737-2741. doi: https://doi.org/10.20546/ijcmas.2019.804.318 